\title{
Mantle Cell Lymphoma
}

\author{
Sascha Dietrich
}

\subsection{Introduction}

Mantle cell lymphoma (MCL) is an aggressive B-cell lymphoma, which is characterized by the chromosomal translocation $\mathrm{t}(11 ; 14)(\mathrm{q} 13 ; \mathrm{q} 32)$ and overexpression of cyclin D1 in the vast majority of cases. Most patients present with advanced stage disease, often with extra-nodal dissemination, and an unfavourable clinical course. Treatment with conventional chemotherapy resulted in unsatisfactory outcomes and a median survival of less than 3 years after diagnosis of MCL (Zucca et al. 1995).

\subsection{Autologous HSCT}

During recent years, the prognosis of patients with MCL has improved considerably, and the refinement of dose-intensified approaches such as auto-HSCT has contributed significantly to this development. A prospective randomized trial by the European Mantle Cell Lymphoma Network (EMCLN) has demonstrated the superiority of auto-HSCT consolidation over interferon maintenance (Dreyling et al. 2005) in the pre-RTX era. The introduction of RTX and the addition of high-dose cytarabine (HD-ARAC) to the induc-

\footnotetext{
S. Dietrich $(\bowtie)$

Department of Hematology, University Hospital of Heidelberg, Heidelberg, Germany

e-mail: sascha.dietrich@med.uni-heidelberg.de
}

tion treatment before auto-HSCT have further improved PFS and OS of MCL patients (Geisler et al. 2008). The benefit of high-dose HD-ARAC before auto-HSCT could be confirmed in prospective clinical trial (Hermine et al. 2016). RTXand HD-ARAC-based induction treatment followed by auto-HSCT is therefore recommended as a first-line treatment standard for young and fit MCL patients (Cheah et al. 2016; Dreyling et al. 2017).

Although a significant proportion of patients with MCL enjoy long-term disease control after auto-HSCT, relapse remains the main cause of treatment failure. The prognosis of patients with MCL recurrence after auto-HSCT appears to be extremely poor, especially if occurring early after transplant (Dietrich et al. 2011; Dietrich et al. 2014a). A proportion of almost $40 \%$ of MCL patients relapsing after auto-HSCT were reported to suffer from chemotherapy-refractory disease (Dietrich et al. 2014a) with a high prevalence of clonal TP53 mutations (Halldorsdottir et al. 2011). In order to prevent these refractory courses, treatment strategies, which effectively reduce the risk of relapse after ASCT, are warranted.

Retrospective studies suggested a significantly improved outcome with RTX maintenance subsequent to high-dose chemotherapy and auto-HSCT for patients with MCL (Dietrich et al. 2014b; Graf et al. 2015). The French study group conducted a prospective randomized phase III trial (LyMa trial) that investigated RTX maintenance versus 
observation after auto-HSCT in previously untreated MCL patients. Final results of the LyMa trial confirmed the superiority of RTX maintenance with regard to PFS and OS (Le Gouill et al. 2017). The beneficial effect of RTX maintenance was observed in both PET-positive and PETnegative patients after induction treatment prior to auto-HSCT (Mei et al. 2017). This finding implies that the benefit of RTX maintenance after autoHSCT is present for low- and high-risk MCL patients.

\subsection{Allogeneic HSCT}

In a large EBMT) registry study, which investigated the outcome of MCL patients after first-line auto-HSCT failure, $24 \%$ of all MCL patients received a rescue consolidation HSCT. Only a minority of $2 \%$ received a second auto-HSCT of whom only one patient experienced a long-term survival. These limited results do not justify a rescue auto-HSCT as reasonable salvage strategy in this situation. In contrast, the majority of patients who received a second HSCT underwent allo-HSCT, and a significant proportion of them achieved a durable remission, translating into a 3-year OS of 43\% (Dietrich et al. 2014a). Other registry studies and single-centre experiences report similar results (Cook et al. 2010; Tam et al. 2009; Le Gouill et al. 2012).

Long-term efficacy of RIC allo-HSCT was recently demonstrated in a large cohort of MCL patients (Robinson et al. 2018). The cumulative incidence of relapse was $40 \%$ at 5 years, and OS was $40 \%$ at 5 years. Patients who developed a chronic GVHD and/or patients who did not receive an in vivo TCD with CAMPATH had a significantly lower relapse rate, suggesting the existence of a graft versus MCL effect. Despite long-term remissions after allo-HSCT, chemorefractory disease (Robinson et al. 2018) or early relapse after first-line auto-HSCT (Dietrich et al. 2014a) significantly reduced the long-term survival of MCL patients after alloHSCT. Chemotherapy-free salvage treatments are obvious options for these highly refractory patients. A recent EBMT survey suggested that ibrutinib may improve the perspective of refractory patients scheduled for allo-HSCT (Dreger et al. 2018). It is important to note that there is a small group of relapsed MCL patients who survived longer than 5 years even without alloHSCT, suggesting a rather indolent disease course in a subset of patients (Dietrich et al. 2014a). Such patients with a low percentage of Ki67-positive tumour cells might not benefit from an allo-HSCT.

\section{Key Points}

- First-line auto-HSCT and RTX maintenance is currently challenged against auto-HSCT with ibrutinib maintenance or a transplant-free approach with ibrutinib and chemotherapy in an EMCLN study (TRIANGLE).

- As long as we await these data to redefine the value of auto-HSCT in the ibrutinib era, auto-HSCT and RTX maintenance should be recommended as the standard treatment for transplanteligible patients with MCL.

- A second auto-HSCT does not appear to be a promising option in patients with MCL failing a first auto-HSCT. For these patients allo-HSCT should be considered.

\section{References}

Cheah CY, Seymour JF, Wang ML. Mantle cell lymphoma. J Clin Oncol. 2016;34:1256-69.

Cook G, Smith GM, Kirkland K, et al. Outcome following Reduced-Intensity Allogeneic Stem Cell Transplantation (RIC AlloSCT) for relapsed and refractory mantle cell lymphoma (MCL): a study of the British Society for Blood and Marrow Transplantation. Biol Blood Marrow Transplant. 2010;16:1419-27.

Dietrich S, Tielesch B, Rieger M, et al. Patterns and outcome of relapse after autologous stem cell transplantation for mantle cell lymphoma. Cancer. 2011;117:1901-10.

Dietrich S, Boumendil A, Finel H, et al. Outcome and prognostic factors in patients with mantle-cell lymphoma relapsing after autologous stem-cell transplantation: a retrospective study of the European Group 
for Blood and Marrow Transplantation (EBMT). Ann Oncol. 2014a;25:1053-8.

Dietrich S, Weidle J, Rieger M, et al. Rituximab maintenance therapy after autologous stem cell transplantation prolongs progression-free survival in patients with mantle cell lymphoma. Leukemia. 2014b;28:708-9.

Dreger P, Michelet M, Bosman P, et al. Ibrutinib for bridging to allogeneic stem cell transplantation (alloHCT) in chronic lymphocytic leukemia (CLL) and mantle cell lymphoma (MCL) is safe and effective update results of a study by the EBMT Chronic Malignancy and the Lymphoma Working Parties, the French Cooperative Group for CLL and the Société Française de Greffe de Moelle et de Therapie Cellulaire (SFGM-TC). Bone Marrow Transplant. 2018. https://doi.org/10.1038/ s41409-018-0207-4. [Epub ahead of print].

Dreyling M, Lenz G, Hoster E, et al. Early consolidation by myeloablative radiochemotherapy followed by autologous stem cell transplantation in first remission significantly prolongs progression-free survival in mantle-cell lymphoma: results of a prospective randomized trial of the European MCL Network. Blood. 2005; 105:2677-84.

Dreyling M, Campo E, Hermine O, et al. Newly diagnosed and relapsed mantle cell lymphoma: ESMO Clinical Practice Guidelines for diagnosis, treatment and follow-up. Ann Oncol. 2017;28:iv62-71.

Geisler CH, Kolstad A, Laurell A, et al. Long-term progression-free survival of mantle cell lymphoma after intensive front-line immunochemotherapy with in vivo-purged stem cell rescue: a nonrandomized phase 2 multicenter study by the Nordic Lymphoma Group. Blood. 2008;112:2687-93.

Graf SA, Stevenson PA, Holmberg LA, et al. Maintenance rituximab after autologous stem cell transplantation in patients with mantle cell lymphoma. Ann Oncol. 2015;26:2323-8.

Halldorsdottir AM, Lundin A, Murray F, et al. Impact of TP53 mutation and $17 \mathrm{p}$ deletion in mantle cell lymphoma. Leukemia. 2011;25:1904-8.

Hermine O, Hoster E, Walewski J, et al. Addition of high-dose cytarabine to immunochemotherapy before autologous stem-cell transplantation in patients aged 65 years or younger with mantle cell lymphoma (MCL Younger): a randomised, open-label, phase 3 trial of the European Mantle Cell Lymphoma Network. Lancet. 2016;388:565-75.

Le Gouill S, Kroger N, Dhedin N, et al. Reduced-intensity conditioning allogeneic stem cell transplantation for relapsed/refractory mantle cell lymphoma: a multicenter experience. Ann Oncol. 2012;23:2695-703.

Le Gouill S, Thieblemont C, Oberic L, et al. Rituximab after autologous stem-cell transplantation in mantlecell lymphoma. N Engl J Med. 2017;377:1250-60.

Mei MG, Cao TM, Chen L, et al. Long-term results of high-dose therapy and autologous stem cell transplantation for mantle cell lymphoma: effectiveness of maintenance rituximab. Biol Blood Marrow Transplant. 2017;23:1861-9.

Robinson SP, Boumendil A, Finel H, et al. Long-term outcome analysis of reduced-intensity allogeneic stem cell transplantation in patients with mantle cell lymphoma: a retrospective study from the EBMT Lymphoma Working Party. Bone Marrow Transplant. 2018;53:617-24.

Tam CS, Bassett R, Ledesma C, et al. Mature results of the M. D. Anderson Cancer Center risk-adapted transplantation strategy in mantle cell lymphoma. Blood. 2009; 113:4144-52.

Zucca E, Roggero E, Pinotti G, et al. Patterns of survival in mantle cell lymphoma. Ann Oncol. 1995;6:257-62. 
Open Access This chapter is licensed under the terms of the Creative Commons Attribution 4.0 International License (http://creativecommons.org/licenses/by/4.0/), which permits use, sharing, adaptation, distribution and reproduction in any medium or format, as long as you give appropriate credit to the original author(s) and the source, provide a link to the Creative Commons license and indicate if changes were made.

The images or other third party material in this chapter are included in the chapter's Creative Commons license, unless indicated otherwise in a credit line to the material. If material is not included in the chapter's Creative Commons license and your intended use is not permitted by statutory regulation or exceeds the permitted use, you will need to obtain permission directly from the copyright holder.

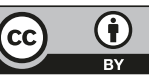

